\title{
Re-Accessing International Capital Markets After Financial Crises: Some Empirical Evidence
}

\author{
Luisa Zanforlin
}





\title{
IMF Working Paper
}

\author{
MCM \\ Re-Accessing International Capital Markets After Financial Crises: Some Empirical \\ Evidence
}

Prepared by Luisa Zanforlin ${ }^{1}$

Authorized for distribution by Carlos Medeiros

June 2007

\begin{abstract}
This Working Paper should not be reported as representing the views of the IMF.

The views expressed in this Working Paper are those of the author(s) and do not necessarily represent those of the IMF or IMF policy. Working Papers describe research in progress by the author(s) and are published to elicit comments and to further debate.
\end{abstract}

The paper analyzes the factors that contribute to the re-access of countries that emerge from a severe financial crisis to the international capital markets. It conjectures that these factors depend on a sovereign's commitment and ability to repay its foreign debt, signaled by sound macroeconomic policies, and the global liquidity environment. Using panel data for 49 countries over a 24-year period, the analysis uses a simple probit approach to show that, indeed, a sustainable debt profile and a sound external position, accompanied by a favorable global liquidity environment, are key factors in affecting the likelihood a sovereign reaccesses international capital markets.

JEL Classification Numbers:F34, G15, O10

Keywords: Sovereign Debt, Re-access, International Finance, Developing Countries Author's E-Mail Address:Lzanforlin@imf.org

\footnotetext{
${ }^{1}$ I am grateful to Mr. Gero Jung from the Swiss Central Bank for his contributions to an early version of this paper. I would like to thank Charlie R. Blitzer, Alberto Chong, Carlos Medeiros, Ugo Panizza, and Juan Solé for many useful comments and suggestions. The usual disclaimer applies.
} 


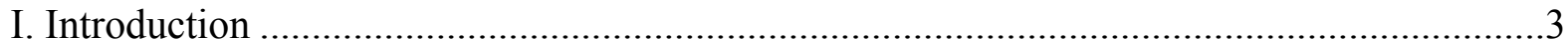

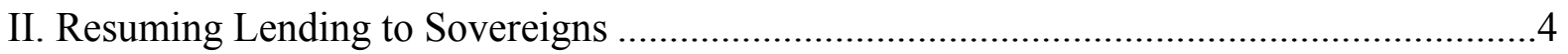

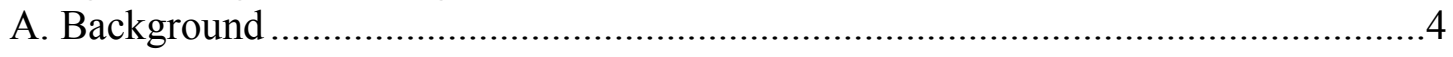

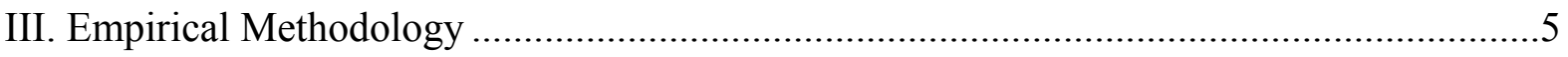

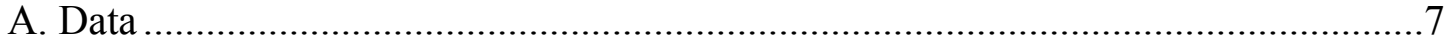

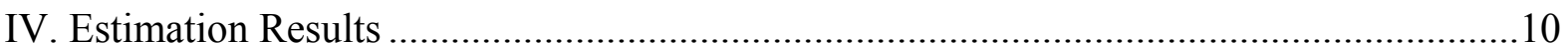

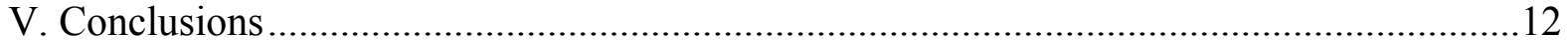

Tables

1. Countries and Episodes of Crisis and Reaccess in the Full Sample 1980-2003 ...............13

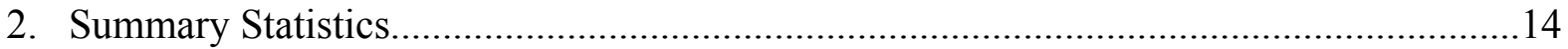

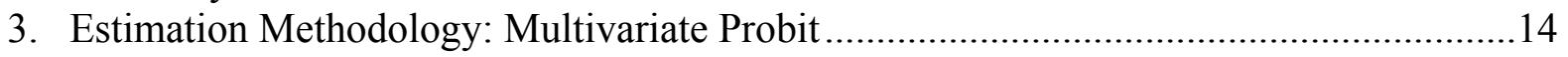

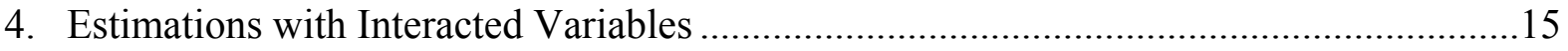

5. Estimation Methodology: Probit with Instrumental Variables ...........................................16

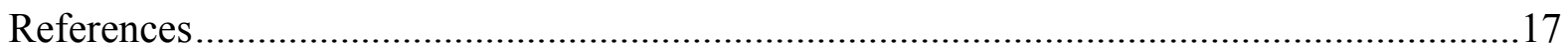

Appendix






\section{INTRODUCTION}

Over the past years, a number of countries have experienced severe financial crises, in some cases so severe that foreign debt had to be restructured. Such episodes have generally entailed a loss of access to international capital markets, which, in certain instances, have lasted many years. However, despite the extent and the severity of such crises, recent experience has shown that, in the majority of cases, countries emerging from a financial crisis have been able to reaccess international capital markets successfully.

In the sovereign debt literature, it has often been argued that international creditors would be reluctant to resume lending to debtor sovereigns that have been unreliable in servicing their debt. In particular, a default would indicate that the sovereign is no longer willing to repay or that the claim is not enforceable. (Eaton and Gersovitz 1981, Bulow and Rogoff 1988 and 1989, Atkenson 1991). However, several authors have maintained a sovereign would be able to borrow again despite a default or a restructuring of its obligations if it engaged in significant efforts to rebuild its reputation as a creditworthy borrower (Diamond 1989; Cole, Dow and English 1995).

On the empirical side, a series of IMF studies have documented and analyzed the circumstances the surrounding the event of reaccessing capital markets by a country emerging from a crisis (IMF 2001a, 2001b, 2003a, 2003b, 2005). A number of empirical regularities were observed in the cases examined, in particular that, in many cases, the implementation of sound macroeconomic policies accompanied by a strong domestic and external position was a pre-condition for reaccessing the markets.

Econometric analysis has mostly focused on the more general question of how a sovereign gains access to capital markets without focusing particularly on the cases of sovereigns seeking new financing after experiencing difficulties in servicing their debt (Gelos et al. 2004, Grigorian 2003). Thus, there is little evidence on any factor specifically affecting countries that suffered financial crisis as opposed to any country wishing to access capital markets.

The aim of this paper is to analyze episodes of countries that have emerged from a severe financial crisis, including through a restructuring of their debt, and to investigate empirically the main determinants of their reaccess to international capital markets. This study conjectures that a sovereign signals its intention of rebuilding its reputation as a creditworthy borrower through the implementation of sound macroeconomic policies and strong economic performance. Creditors then evaluate the case to resume lending on the basis of their expected returns in the context of the global liquidity cycle. Using panel data for 49 countries over a 24-year period and a set of episodes of financial crisis, the analysis uses a simple probit approach to analyse which factors affect most the likelihood that a country would be able to successfully re-access the debt markets.

The paper is organized as follows: Section II discusses briefly the main theoretical models for lending resumption after default and the recent empirical evidence on the determinants of market acces following a default; section III decribes the empirical methodology, the data 
definition, and sources; and section IV reviews the estimation results under different econometric methodologies and dependent variables definitions. Section V briefly concludes.

\section{RESUMING LENDING TO SOVEREIGNS}

\section{A. Background}

There are two complementary views regarding the ability of countries to re-access international financial markets after a financial crisis. On the one hand, the literature on sovereign debt has shown that governments have an incentive to meet their obligations and to preserve their reputation as creditworthy borrowers because uninterrupted financing flows imply a higher level of consumption or because repayment is enforced by a credible threat from creditors of possible economic and political sanctions (Bulow and Rogoff 1988, 1989). In either case, creditors are willing to lend because they are confident that repayment will occur (Eaton and Gersovitz 1981). However, some authors suggest that sovereigns will have difficulties obtaining new financing after defaulting (Bulow and Rogoff 1988, 1989; Atkenson 1991).

On the other hand, it has been argued that, despite an event of default, a sovereign will be able to borrow again if creditors differentiate between a justifiable default and debt repudiation or if the country engages in significant efforts to rebuild its reputation as a creditworthy borrower. The nature of the crisis that led a sovereign to default may therefore be important to explain why creditors' financing resumed. If creditors concluded that the default reflected exogenous factors, the sovereign's reputation as a trustworthy borrower would remain untarnished and financial flows to sovereign would continue even in the face of numerous episodes of default (Grossman and van Huyck 1988).

This argument has led many to conclude that a debtors' reputation is the main determinant of lending (Cole, Dow and English 1995). According to this view, a sovereign will be able to re-access international capital markets provided it shows renewed commitment to service its obligations and financial means to support it. The specific mechanism to rebuild trustworthiness may be through the adoption of a comprehensive set of sound economic policies, for example, austerity programs, which signal both political stability and a solid financial position.

Lenders will also evaluate their expected returns prior to resuming lending. Thus, reputation of a sovereign borrower would then be closely linked to the return on the projects it is undertaking with loaned funds and would need to assure creditors that the return from such projects remain positive in their projection period (Diamond 1989, Atkenson 1991, and, more recently, Sole 2004).

The existing empirical evidence shows that sovereigns tend to service their debt. In this light, not surprisingly, such debt typically yields positive ex-post returns above the cost of funding (Eichengreen and Portes 1986; Lindert and Morton 1990; Klingen, Zettelmeyer and Weder 2004). However, there is little evidence on what determines lending to resume to countries that suffered financial crises and structural institutional weakness. For instance, Gelos et al. (2004) and Grigorian (2003) investigate the circumstances under which a country gains 
access to international capital markets, but do not focus on the specific case of sovereigns seeking new financing after experiencing a financial crisis. In this context, the aim of this paper is to focus specifically on the issue of market re-access after countries have undergone financial and debt crisis.

\section{EMPIRICAL METHODOLOGY}

The variable of interest is the event of re-accessing the markets, which, may be defined as a categorical event. For instance, a country may be given full access to international capital markets by selling a new bond, or no access at all. Here, the focus is on the particular case where the variable of interest or dependent variable is dichotomous for several reasons. First, the aim of this study is to analyze the determinants of the event of re-accessing the markets: a continuous variable representing such event, such as, for example, the volume of the reaccess issues, would also depend on considerations other than those that allow just for the event of re-access, including, for example, the financing needs. Second, it would be difficult to identify an ordinal dependent variable by identifying different categories of re-access, as those generated, for example, by categories of partial access levels. Finally, the interpretation of the results is, typically, much more straightforward when using simple probits rather than ordered probits, as in the latter case, marginal effects are produced for each re-access category.

In particular, a simple probit technique makes it possible to take into consideration the binary nature of the dependent variable in this study, namely whether a country has access or not to international capital markets. For instance, in the case of two degrees of re-access categories, the empirical model follows the following specification:

$$
\begin{aligned}
& \operatorname{Pr} o b\left(Y_{i}=0\right)=\Phi\left(\beta^{\prime} X\right) \\
& \operatorname{Pr} o b\left(Y_{i}=1\right)=1-\Phi\left(\beta^{\prime} X\right)
\end{aligned}
$$

where $Y_{i}$ is a random variable indicating whether a country re-accesses markets after a crisis, which takes a value of 0 if there is no new issue and a value of 1 when a new bond is sold in the market following the crisis; $X$ is a vector of domestic policies (commitment to pay), external circumstances (ability to pay), and global characteristics, and the function $\Phi($.$) is$ the standard normal probability distribution.

The log-likelihood can be derived for the two possible outcomes as:

$$
\ln L=\sum_{i=1}^{n}\left\{y_{i} \ln \Phi\left(\beta^{\prime} x\right)+\left(1-y_{i}\right) \ln \left[1-\Phi\left(\beta^{\prime} x\right)\right]\right\}
$$

Once the likelihood is formed, the estimation of the unknown parameters $\beta^{\prime} s$ can be undertaken by maximizing the log-likelihood function (2). The impact of a change in an explanatory variable on the estimated probabilities of the event of re-access is direct. For instance, if $\beta_{k}$ is positive, an increase in $x_{k}$ increases the probability of re-accessing and decreases the probability of not re-accessing. Note that an estimated $\beta$ value does not 
estimate the change in probability of a given outcome. By manipulation of (1), it can be shown that that the marginal effects of the attributes on the corresponding probabilities are:

$$
\frac{\partial E\left(y_{i} / x_{k}\right)}{\partial x_{k}}=+\phi\left(\beta^{\prime} X\right) \beta_{k}
$$

While the data include a panel with observations across countries and years, a random effects estimator ${ }^{2}$ is not considered as the best estimator because the consistency of the random effects estimator requires that individual effects are uncorrelated with explanatory variables. However, the explanatory variables for the re-access event is comprised of cross-country macroeconomic variables which typically tend to depend on country specific characteristics, such as the institutional framework. Thus, the random effect estimator would be inconsistent.

The case for applying fixed effects in probit estimations is even more complex. ${ }^{3}$ In particular, fixed effect coefficients are subject to severe biases due to the incidental parameters problem as noted in Hsiao $(1993,1996)$ and Green $(2004) .{ }^{4}$ However, the inclusion of global liquidity indicators among the explanatory variables, as represented by the yield on US Treasury debt-instruments, does allow to control for business cycle-type of effects (time effects) across the estimations.

All regressions were corrected for heteroskedasticity in errors. To avoid high correlation between some of the indicators of macroeconomic policies and the country's own growth rate, the growth rates were included in lagged form. ${ }^{5}$ To perform sensitivity analysis of the estimates to specific variable selection, different indicators were used to proxy for external and domestic macroeconomic soundness and were introduced alternatively in the regressions.

While theoretically endogeneity may be a problem, the size of a bond issue is typically very small in comparison with the macroeconomic magnitudes of the typical regressors in the equation. It seems unreasonably difficult that a new bond would affect the size of the current account balance or the rate of inflation. However, to check for this possibility, the probit

\footnotetext{
${ }^{2}$ A random effects estimator assumes that there are group specific turbulences, which would imply that individual effects are randomly distributed across cross-sectional units. This implies estimating $u_{i}$, a random disturbance characterizing the $i$ th observation which is constant through time. This approach is typical when cross-sectional units are drawn from a large population (Green 1997 p. 623).

${ }^{3}$ Fixed effect estimators assume that the differences across units of the panel (in this case countries) are constant, i.e. that there are group-specific differences that can be captured by a constant term. In practice this implies estimating an additional parameter in the linear regression $\alpha_{i}$, an individual effect, which is taken to be constant over time and specific to the cross-sectional unit $i$ (in this case countries) (Green 1997 p. 615).

${ }^{4}$ Even in the case the chosen methodology would have been logit estimations, it would not have been possible to apply fixed country effects to the estimations because the method to remove group heterogeneity would have implied excluding from the sample all the countries that having experienced a crisis did not re-access international capital markets during the period under consideration (Green 1997).

${ }^{5}$ Findings do not change if lags are not included.
} 
parameters were also estimated using an instrumental variables approach with lagged values as instruments. In all regressions, the significance and direction of the estimated coefficients were unchanged by the use of instruments, thus suggesting that the biases due to endogeneity in the probit estimates were limited.

Finally, a number of regressions were run by including interactive terms to control for the way the sovereign managed the financial crisis, either through a debt reduction or by negotiating exceptional liquidity support, thereby committing upfront to sound macroeconomic policies while averting losses to the creditors. For this purpose, two dummy variables were constructed, one to identify the episodes of crisis were the sovereign restructured bonds or loans and the other to identify episodes where an exceptional access facility was granted by the IMF and debt restructuring was averted. The interactive variables were constructed by multiplying each dummy with the different macroeconomic variables signaling creditworthiness. The advantage of this approach is that it allows to identify if the coefficients impacting the probability of re-access depend on whether the creditors suffered a financial loss from the crisis or not.

\section{A. Data}

A sovereign that has undergone a financial crisis will be able to re-access the markets if it signals a commitment and ability to repay its debt and if investors value favorably the returns from resuming lending. As mentioned above, macroeconomic indicators of these conditions will then constitute the explanatory variables of the equation modeling the probability that a sovereign re-accesses the markets.

In particular, a sovereign's commitment of a country to repay foreign currency debt may be proxied by domestic policy indicators, including the domestic rate of inflation, the fiscal balance, the total stock of outstanding debt, and a political conditions index. Low inflation, debt ratios and fiscal deficit provides a signal for sound domestic macroeconomic management. The inclusion of an institutional index provides an indication of good governance practices in the country.

A sovereign's ability to repay foreign currency debt may be proxied by external variables, such as the total amount of reserves as a share of short term debt, total debt service as a share of reserves, the level of reserves in terms of months of imports, as well as the external current account balance. High levels of reserves and low current account deficits indicate a country's strong external position. The presence of an IMF program may be considered as a signal for a country's ability to repay as it provides liquidity support.

Investors' expected returns from resuming lending may be proxied by an indicator of economic activity, in particular GDP growth rates, which were assumed to represent the real return from investment in the country. 
Finally, global liquidity conditions may be proxied by yields on U.S. Treasury debt instruments. The lower these yields, the higher global liquidity and the more likely investors lend to emerging market countries. ${ }^{6}$

It is important to note that GDP growth rates and fiscal deficits not only signal to creditors the expected returns or the sovereign's commitment to repay but also reflect the sovereign's own demand for foreign financing. In effect, fiscal deficit would represent a financing need and GDP growth would well represent trends in domestic demand. Therefore, including such variables in the regressions provides also a control for the sovereigns' demand for new financing. Ultimately, this implies that the expected sign for on the estimated coefficient for fiscal deficits will be uncertain depending on which of the two effects (commitment to repay or demand for financing) prevails in the empirical data: the estimated sign will provide an indication of which between commitment to repay or domestic demand conditions are more important in determining the event of re-access. In the case of GDP growth rates, both effects from the signaling increasing returns and the domestic demand for new financing would increase the probability of reaccessing the markets.

To minimize issues of cross-correlation and joint endogeneity across explanatory variables, only one indicator for each condition for re-access was included in the estimations at a time. In addition, lagged GDP growth rates were included, as they tend to be associated with many macroeconomic indicators. Alternative specifications of the same indicator, as discussed above, were used to perform sensitivity analysis. In this way, the different proxies for the ability to pay, the current account balance, the debt ratio, and the reserve ratios were introduced alternatively in the baseline equation. This made it possible both to evaluate which signal of ability to pay was most significant in affecting the likelihood a country reaccessed the markets and to analyze the sensitivity of the estimates for coefficients on the other explanatory variable. The same system was applied for indicators of the commitment to repay.

The dataset comprises of 49 emerging market countries that have been active issuers in the international capital markets with annual data over the period 1980-2003. ${ }^{7}$ Data on financial crises have been compiled and divulged by Standard and Poor's regular publications and comprises a set of episodes in which sovereigns either defaulted or restructured their external obligations, which resulted in a loss to the creditors. ${ }^{8}$

\footnotetext{
${ }^{6}$ A number of regressions were also run with alternative macroeconomic indicators than the ones mentioned above, in particular, monetary conditions indexes for commitment to repay, exports to total debt as indicator of ability to repay, real interest rates, GDP growth of the U.S. and a volatility in bond markets index as indicators of global cyclical conditions, but were not found to be significant.

${ }^{7}$ Appendix 1 lists the countries included in this research.

${ }^{8}$ Global bonds have become popular only since the early nineties and earlier forms of external financing for emerging market countries mainly took the form of syndicated loans.
} 
A default, according to $\mathrm{S} \& \mathrm{P}$, is an episode where an obligor fails to meet a principal or interest payment on the due date, or within the specified grace period, contained in the original terms of the debt issue. In particular, (i) in the case of local and foreign currency bonds, notes, and bills, each issuer's debt is considered in default either when scheduled debt service is not made on the due date or when an exchange offer of new debt contains less favorable terms than the original issue; and (ii) in the case of bank loans, when either scheduled debt service is not made on the due date or a rescheduling of principal and/or interest is agreed to by creditors at less favorable terms than the original loan. Such rescheduling agreements covering short- and long-term bank debt are considered a default even where, for legal, or regulatory reasons, creditors deem forced rollover or principal to be voluntary (Chambers and Alexeeva 2002).

While in the set of episodes compiled by S\&P, a financial crisis was eventually resolved by a debt reduction through a restructuring its obligations, in other circumstances, exceptional liquidity support from multilateral financial institutions may have helped the sovereign to remain current on its bilateral obligations while facing a financial crisis. In this respect, Manasse, Roubini, and Schimmelpfennig (2003) have identified episodes of financial crisis in which sovereigns were granted access to exceptional liquidity support by multilateral financial institutions. In particular, the sovereigns were allowed access to IMF financing for over 100 percent of their quota, but did not result in a "default" according to S\&P.

It is important to note that in the episodes where the financial crisis was resolved through exceptional liquidity support, private creditors did not suffer any loss from lending, an outcome that is different from the episodes compiled by S\&P. However, in both cases, the financial crisis entailed a loss of market access for the sovereign. As an additional observation, countries had to commit upfront to sound macroeconomic policies to qualify for a disbursement under the exceptional financing facility, thus providing "ipso facto" a signal for strong commitment-to-repay their external debt.

On the initial dataset, using both of the definitions of crisis discussed above, it was possible to identify a sample of 53 episodes of financial crisis which took place across 27 different countries. In 45 cases, the crisis required that a bond or a loan to the sovereign be restructured, while in 8 cases the sovereign was granted exceptional liquidity support via access to financing from IMF without having to restructure any of its obligations. Episodes of restructuring of both loans and bonds to the sovereigns were included in the sample because the greater part of sovereign lending in 1980-90 took the form of syndicated loans.

The event of "re-accessing the markets" was defined as the placing of a new sovereign bond in the international capital markets for the first time after a financial crisis. ${ }^{9}$ For the sample of 53 financial crises over the period covered by the database, it was possible to identify 37

\footnotetext{
${ }^{9}$ There are cases in which the first issue by a sovereign after a crisis was made in the domestic capital market but such episodes are excluded for purposes of this analysis as they deviate from the focus of my research.
} 
episodes of first successful international bond issue (re-access to the market) by 26 different sovereigns. ${ }^{1011} 12$

The data on international bond issuances was provided by Bondware Dealogic. This private firm registers single bond issues in the international markets, including the characteristics of each issue, such as amounts, terms, conditions, syndicates, and issuers' characteristics. ${ }^{13}$ The relevant bond issues were compiled by country governments for the period 1980-2003 at the country level. Additionally, institutional data were obtained from the well-known International Country Risk Guide dataset (ICRG, 2006). These data were originally used by Knack and Keefer (1995), Hall and Jones (1999), and several other researchers. The ICRG risk rating system assigns a numerical value to a predetermined range of risk components for about 130 countries. In this paper, the five most commonly used institutional dimensions used in the literature are used: (i) government stability; (ii) corruption; (iii) law and order; (iv) democratic accountability; and (v) bureaucracy quality. As in Knack and Keefer (1995), annual averages of these five dimensions for 1980-2003 were computed. Additionally, the macroeconomic indicators were taken from the IMF (2006) and from the World Bank (2006). Finally, data on IMF programs are available at the website of the International Monetary Fund. $^{14}$

\section{ESTIMATION RESULTS}

Table 1 shows the basic summary statistics of all the variables utilized in this paper. Table 2 presents the marginal effects and corresponding statistically significance of the multivariate simple probit estimates for all countries that underwent a financial crisis. The first column contains the chosen baseline regression, as it presents the best fit. In this specification, the probability that a country would re-access the markets will be affected by the global liquidity cycle, total debt to GDP to indicate the domestic policy stance, the level of the current account to signal the external position, and the lagged GDP rate to indicate the return from investment in the country. The subsequent columns conduct sensitivity analysis with respect to the baseline specification and, at the same time, control whether a sovereign could be

\footnotetext{
${ }^{10}$ All episodes where new financing was achieved through a loan syndication were excluded from the sample as this form of financing involves only very few lenders. In addition, loan financing has become a secondary form of financing emerging markets sovereigns during the last decade. This definition differs from that used in Gelos et al. (2004) who define "re-access event" as both new bond issuance and new loan syndication.

${ }^{11}$ It is important to note that any issuance of bonds in exchange for existing bonds following a restructuring agreement between a sovereign and its creditors in the context of a resolution of a financial crisis was not considered as an episode of re-access. By example, the so-called Brady bonds issued after the large debt crisis in Latin America at the end of the 1980s were not considered an event of re-access.

${ }^{12}$ Notwithstanding this statistics, the number of episodes where countries had to restructure their bonds remains limited to date, as such events are still quite rare in international financial markets.

${ }^{13}$ The quality of the information provided by this firm is confirmed by the fact that it sells this product at a high price and after a number of years the demand for its product in both the private and public sectors is still very strong.

${ }^{14} \mathrm{http} / / /$ www.imf.org
} 
using different indicators to signal either commitment or ability to repay and, thus, whether such variables are also significant in determining re-access to markets. In particular, columns 2 to 5 in the same table include different indicators of the domestic policy stance other than the total stock of total debt to GDP to signal commitment-to-repay, while columns 6 to 10 include alternative indicators of the external position, in particular indicators of reserve levels, to signal a sovereign's ability to repay its foreign debt.

The elements that appeared to impact most significantly the probability that a sovereign would re-access markets are its perceived ability to repay as signaled by the current account deficit, and the global liquidity cycle, as proxied by the yields on U.S. Treasury debt instruments. In particular, according to the marginal impact on the probability, a one percentage point increase in the yields of U.S. treasury notes reduces the probability of reaccessing the markets by, on average, 13 percent for any one year. In the case indicators of ability to repay, a one percent improvement in the current account deficit was found to increase the probability of re-access by, on average, 20 percent. A sovereign's commitment to repay as signaled by indicators of sound domestic policies - debt levels, inflation levels and domestic political conditions - also seemed to be a significant determinant of re-access. However, the size of their impact appeared to be limited. Finally, investors' expected returns from the new lending, as proxied by lagged GDP growth rates, also appeared to impact the probability of re-access, although the estimates were not very robust.

Table 3 presents the results of the estimations when some of the explanatory variables of the general regression are interacted with dummies variables which define the type of financial crisis the countries underwent prior to re-access. As in Table 2, column 1 reports the baseline regression. Column 2 shows the results for the estimation when the baseline indicator of a country's commitment to pay is interacted with a dummy that identifies all countries that defaulted (according to S\&P definition). Column 3 presents the estimation results when the baseline indicator of the ability to pay is interacted with the dummy identifying countries that received exceptional liquidity support and did not restructure their debt. Column 4 presents the estimates when a short-term indicator of the ability to pay is included, i.e. the level of debt service to reserves. ${ }^{15}$ Column 5 and 6 show the estimates when both the interactive variables specified over countries that defaulted and those that received liquidity support are included in the equation. The regressions with interacted variables highlight how indicators of commitment to repay, such as the total debt level to GDP, appear to have a significant impact on the probability of re-access in those cases where debt was restructured and creditors suffered losses. However, debt sustainability indicators tend not to be significant in those cases where access to liquidity support was granted. In such cases, indicators of the ability to pay, such as the current account deficit and the level of debt service to reserves, which are more short-term in nature, appear to have a stronger impact on the probability of re-accessing the market than for the rest of the sample.

Table 4 presents the estimates when instrumental variables are used in the probit to control for possible endogeneity biases among explanatory variables, where lagged values of the

\footnotetext{
${ }^{15}$ Interactive estimations with other proxies for the ability to repay were run but were not found to be significant.
} 
explanatory variables were used as instruments. ${ }^{16}$ The most noticeable outcome is that, in all regressions, the significance and direction of the estimated coefficients were unchanged by the use of instruments, thereby suggesting that the biases due to endogeneity in the probit estimates were limited.

\section{CONCLUSIONS}

This paper conjectures that a sovereign that is emerging from a financial crisis signals its intention to become a creditworthy borrower by making a commitment to repay through the adoption of sound domestic macroeconomic policies and signals its ability to repay foreign debt though indicators of external soundness. Foreign investors evaluate whether to resume lending on the basis of the expected rate of return of their investment subject to the global liquidity cycle. This paper has sought to analyze which set of macroeconomic indicators increases the likelihood that a sovereign emerging from a crisis will re-access international capital markets.

Estimation results provide support to the conjecture that signals of both the commitment and the ability to repay external obligations are statistically significant when a sovereign seeks to re-access market. In particular, indicators of external soundness appear to have a relatively larger impact and, to be particularly effective in the case of countries that, despite suffering a crisis, were able to avoid restructuring their debt.

The results also show that international investor demand is fundamental when countries seek re-access to markets as the global liquidity cycle appears to be a factor that significantly affects the likelihood of re-accessing. In general, other indicators of a sound macroeconomic stance, including the presence of an IMF program, a signal of a country's commitment to sound macroeconomic policies, are also statistically significant in determining re-access.

The results also evidence how lenders, when considering whether to resume new lending, differentiate between countries that defaulted (according to the S\&P definition) and countries that were able to avert a default by negotiating exceptional liquidity support. In particular, total debt ratios were found to be significant in increasing the likelihood of re-access only for sovereigns which underwent a restructuring of their obligations. This suggests that, in such cases, creditors take into consideration long-term debt-sustainability indicators when evaluating whether to resume lending. In contrast, the size of the impact of external soundness indicators was found to largest in increasing the likelihood of re-access of countries that did not restructure their obligations, which suggest that creditors, in such cases, focus on indicators of the ability-to-repay, which tend to be more of a short-term nature.

To conclude, the estimation results support the theoretical prediction that, overall, sound domestic policies and external indicators, together with a favorable global liquidity environment are key considerations for creditors' considering whether to resume lending to sovereigns that went through financial crises.

\footnotetext{
${ }^{16}$ The table reports Wald test of exogeneity after instrumental variable estimates.
} 
Table 1. Countries and Episodes of Crisis and Reaccess in the Full Sample 1980-2003 1/2/3/

\begin{tabular}{|c|c|c|c|}
\hline \multicolumn{2}{|c|}{ List of Crisis Episodes } & \multicolumn{2}{|c|}{ List of Reaccess Episodes 1980-2003 } \\
\hline Country & Year & Country & Year \\
\hline Argentina & 1982 & --- & --- \\
\hline Argentina & 1989 & Argentina & 1991 \\
\hline Argentina & $1995 * 4 /$ & Argentina & 1996 \\
\hline Argentina & 2001 & --- & --- \\
\hline Brazil & 1983 & Brazil & 1995 \\
\hline Brazil & $1998 *$ & Brazil & 1999 \\
\hline Brazil & $2002 *$ & Brazil & 2002 \\
\hline Chile & $19835 /$ & Chile & 1999 \\
\hline Costa Rica & 1981 & --- & --- \\
\hline Costa Rica & 1984 & Costa Rica & 1998 \\
\hline Croatia & $19925 /$ & Croatia & 1996 \\
\hline Dom Republic & 1982 & --- & --- \\
\hline Dom Republic & 1999 & Dom Republic & 2001 \\
\hline Ecuador & $19825 /$ & Ecuador & 1997 \\
\hline Ecuador & 1999 & --- & --- \\
\hline Egypt & $19845 /$ & Egypt & 2001 \\
\hline Guatemala & $19865 /$ & --- & --- \\
\hline Guatemala & 1989 & Guatemala & 1997 \\
\hline Indonesia & 1998 & --- & --- \\
\hline Indonesia & $20025 /$ & Indonesia & 2003 \\
\hline Jamaica & $19815 /$ & --- & --- \\
\hline Jamaica & $19885 /$ & Jamaica & 1997 \\
\hline Korea & $1997 *$ & Korea & 1998 \\
\hline Mexico & $19825 /$ & Mexico & 1988 \\
\hline Mexico & $1994 *$ & Mexico & 1995 \\
\hline Moldova & 1998 & --- & --- \\
\hline Moldova & 2002 & --- & --- \\
\hline Morocco & $19835 /$ & --- & --- \\
\hline Morocco & $19865 /$ & --- & --- \\
\hline Morocco & $19905 /$ & Morocco & 1996 \\
\hline Pakistan & 1998 & --- & --- \\
\hline Pakistan & 1999 & Pakistan & 2003 \\
\hline Panama & $19835 /$ & --- & --- \\
\hline Panama & 1987 & Panama & 1997 \\
\hline Peru & $19805 /$ & --- & --- \\
\hline Peru & $19835 /$ & Peru & 2002 \\
\hline Philippines & $19835 /$ & Philippines & 1993 \\
\hline Russia & 1998 & Russia & 20036 \\
\hline Slovenia & $19925 /$ & Slovenia & 1996 \\
\hline South Africa & $19855 /$ & South Africa & 1988 \\
\hline South Africa & $19895 /$ & South Africa & 1991 \\
\hline South Africa & $19935 /$ & South Africa & 1994 \\
\hline Thailand & $1997 *$ & Thailand & 2001 \\
\hline Turkey & $19825 /$ & Turkey & 1988 \\
\hline Turkey & $2000 *$ & Turkey & 2001 \\
\hline Ukraine & 1998 & Ukraine & 2002 \\
\hline Uruguay & $19835 /$ & --- & --- \\
\hline Uruguay & $19875 /$ & Uruguay & 1992 \\
\hline Uruguay & 1990 & Uruguay & 2002 \\
\hline Uruguay & $2003 *$ & Uruguay & 2003 \\
\hline Venezuela & $19835 /$ & Venezuela & 1988 \\
\hline Venezuela & $19905 /$ & Venezuela & 1991 \\
\hline Venezuela & 1995 & Venezuela & 1996 \\
\hline
\end{tabular}

Sources: S\&P (2003), Manasse et al (2003), Dealogic and Fund staff calculations.

1/ A country is defined as suffering a crisis the year it defaults on a bond or a loan as per Standard \& Poor's definition or in the year it received a non-concessional IMF loan in excess of 100 percent of quota as in Manasse et al. (2003).

$2 /$ A country is defined as having gained reaccess the year it issues a sovereign international bond in the capital markets following a crisis episode.

3/ Reaccess episodes are listed following the closest crisis event by calendar date.

4/ Asterisks denote episodes when countries received non-concessional IMF loan in excess of 100 percent of quota and did not restructure debt.

5/ The country defaulted or restructured foreign currency bank loans.

6/ A large public bank issued a global bond. 
Table 2. Summary Statistics ${ }^{1 /}$

\begin{tabular}{lrrrrr}
\hline \multicolumn{1}{c}{ Variable } & Obs & Mean & Std. Dev. & Min & Max \\
\hline & & & & & \\
$\mathrm{i}_{\mathrm{w}}$ & 624 & 7.16 & 3.76 & 1.01 & 16.87 \\
CA (in percent of GDP) & 648 & -0.01 & 0.06 & -0.17 & 0.52 \\
Debt (In percent of GDP) & 528 & 57.23 & 31.68 & 0.60 & 223.86 \\
$\pi$ & 512 & 107.02 & 502.15 & -1.17 & 7481.66 \\
$\Delta \mathrm{Y}$ & 648 & 2.59 & 5.32 & -34.63 & 13.29 \\
Fiscal primary (in percent of GDP) & 413 & 0.74 & 4.73 & -22.98 & 17.79 \\
Budget balance (in percent of GDP) & 648 & -0.03 & 0.04 & -0.24 & 0.06 \\
Reserves to s.t. debt & 535 & 2.23 & 6.03 & 0.04 & 91.50 \\
Debt service to reserves & 536 & 107.59 & 108.15 & 2.47 & 882.32 \\
Reserves in months of imp & 568 & 3.16 & 2.34 & 0.12 & 12.92 \\
\hline
\end{tabular}

1/ Variable definitions: i w: world interest rates (U.S. T-bill rates); CA: current account balance; Debt: total public debt stock; $\pi$ : inflation rates; $\Delta \mathrm{Y}$ :GDP growth rates; Debt: total debt as a share to GDP; CA: current account reserves to s.t. debt: ratio international reserves in U.S. dollars to short-term debt. Debt service to reserves: ratio of total debt service to reserves; Reserves in months of imp: international reserves in months of imports.

Table 3. Estimation Methodology: Multivariate Probit. Dependent Variable: Reaccess After a Financial Crisis 1/

\begin{tabular}{|c|c|c|c|c|c|c|c|c|c|c|c|}
\hline & & (1) & (2) & (3) & (4) & (5) & (6) & (7) & (8) & (9) & (10) \\
\hline & & Baseline & \multicolumn{5}{|c|}{ Alternative signals of commitment to repay } & \multicolumn{4}{|c|}{ Alternative signals of ability to repay } \\
\hline \multirow[t]{2}{*}{$\begin{array}{l}\text { Global liquidity } \\
\end{array}$} & $i_{W}$ & -0.014 & -0.01 & -0.011 & -0.012 & -0.009 & -0.015 & -0.016 & -0.016 & -0.014 & -0.011 \\
\hline & & $(0.003)^{* * *}$ & $(0.003)^{* * *}$ & $(0.004)^{* *}$ & $(0.002)^{* * *}$ & $(0.005)^{*}$ & $(0.003)^{* * * *}$ & $(0.003)^{* * *}$ & $(0.003)^{* * *}$ & $(0.003)^{* * *}$ & $(0.003)^{* * *}$ \\
\hline \multirow[t]{7}{*}{ Commitment to repay } & Debt & $\begin{array}{l}-0.037 \\
(0.024)\end{array}$ & & & & & $\begin{array}{l}-0.045 \\
(0.027)^{*}\end{array}$ & $\begin{array}{l}-0.051 \\
(0.029)^{*}\end{array}$ & $\begin{array}{l}-0.055 \\
(0.029)^{*}\end{array}$ & $\begin{array}{l}-0.032 \\
(0.024)\end{array}$ & $\begin{array}{l}-0.046 \\
(0.026)^{*}\end{array}$ \\
\hline & $\pi$ & & $\mid \begin{array}{l}0.000 \\
(0.000)^{*}\end{array}$ & & & & & & & & \\
\hline & Fiscal Primary & & & 0.001 & & & & & & & \\
\hline & & & & $(0.00)$ & & & & & & & \\
\hline & Budget Balance & & & & -0.142 & & & & & & \\
\hline & ICRG & & & & & 0.002 & & & & & \\
\hline & & & & & & $(0.001)^{* *}$ & & & & & \\
\hline \multirow[t]{10}{*}{ Ability to repay } & CA & 0.286 & 0.329 & 0.604 & 0.184 & 0.515 & & & & & \\
\hline & & $(0.159)^{*}$ & $(0.167)^{* *}$ & $(0.259)^{* *}$ & $(0.101)^{*}$ & $(0.245)^{* * *}$ & & & & & \\
\hline & Reserves to imp & & & & & & 0.002 & & & & \\
\hline & & & & & & & $(0.00)$ & & & & \\
\hline & Reserves to s.t. debt & & & & & & & 0.000 & & & \\
\hline & Debt service to Reserves & & & & & & & & 0.0000 & & \\
\hline & & & & & & & & & $(0.00)$ & & \\
\hline & CA_1 & & & & & & & & & 0.275 & \\
\hline & IMF program & & & & & & & & & $(0.162)^{*}$ & 0.007 \\
\hline & & & & & & & & & & & $(0.004)^{*}$ \\
\hline \multirow[t]{2}{*}{ Expected return } & $\Delta Y_{-} 1$ & 0.002 & 0.002 & 0.002 & 0.002 & -0.001 & 0.001 & 0.002 & 0.002 & 0.002 & 0.002 \\
\hline & & $(0.001)^{*}$ & $(0.00)$ & $(0.00)$ & $(0.00)$ & $(0.003)$ & $(0.00)$ & $(0.00)$ & $(0.001)^{*}$ & $(0.001)^{*}$ & $(0.001)^{*}$ \\
\hline \multicolumn{2}{|l|}{ Observations } & 486 & 494 & 383 & 598 & 448 & 475 & 458 & 459 & 486 & 377 \\
\hline \multicolumn{2}{|l|}{ Wald } & 25.43 & 20.59 & 11.62 & 27.14 & 19.070 & 25.68 & 26.42 & 26.29 & 29.18 & 19.87 \\
\hline \multicolumn{2}{|l|}{$\log \mathrm{L}$} & -99.54 & -102.91 & -101.24 & -124.46 & -111.86 & -99.78 & -96.28 & -96.25 & -99.62 & -65.63 \\
\hline \multicolumn{2}{|l|}{ Pseudo R2 } & 0.14 & 0.09 & 0.06 & 0.09 & 0.07 & 0.13 & 0.13 & 0.13 & 0.14 & 0.13 \\
\hline
\end{tabular}

Robust standard errors in parentheses

* significant at $10 \% ; *$ significant at $5 \% ; * * *$ significant at $1 \%$

1/ Variable definitions: i w: world interest rates (Us rates); $\Delta \mathrm{Y}$ :GDP growth rates; Debt: total debt to GDP; CA: current account balances; Reserves to imp: reserves in months of imports; Debt service to reserves: ratio of total debt service to reserves; Reserves to s.t. debt: ratio reserves in U.S. dollars to short term debt; icrg:country risk indicator; IMF program: log size approved IMF program. 
Table 4. Estimations with Interacted Variables

\begin{tabular}{|c|c|c|c|c|c|c|c|}
\hline & & $\begin{array}{l}(1) \\
\text { Baseline }\end{array}$ & (2) & (3) & (4) & (5) & (6) \\
\hline Global liquidity & $i_{W}$ & $\begin{array}{l}-0.014 \\
(0.003)^{* * *}\end{array}$ & $\begin{array}{l}-0.013 \\
(0.003)^{* * *}\end{array}$ & $\begin{array}{l}-0.014 \\
(0.003)^{* * *}\end{array}$ & $\begin{array}{l}-0.015 \\
(0.004)^{* * *}\end{array}$ & $\begin{array}{l}-0.012 \\
(0.003)^{* * *}\end{array}$ & $\begin{array}{l}-0.015 \\
(0.003)^{* * *}\end{array}$ \\
\hline Commitment to repay & $\begin{array}{l}\text { Debt } \\
\text { Debt*D/R }\end{array}$ & $\begin{array}{l}-0.037 \\
(0.024)\end{array}$ & $\begin{array}{l}0.113 \\
(0.077) \\
-0.168 \\
(0.084)^{* *}\end{array}$ & $\begin{array}{l}-0.043 \\
(0.025)^{*}\end{array}$ & $\begin{array}{l}-0.033 \\
(0.026)\end{array}$ & $\begin{array}{l}0.041 \\
(0.092) \\
-0.102 \\
(0.097)\end{array}$ & $\begin{array}{l}0.105 \\
(0.076) \\
-0.143 \\
(0.084)^{*}\end{array}$ \\
\hline \multirow[t]{2}{*}{ Ability to repay } & $\mathrm{CA}$ & \multirow[t]{2}{*}{$\begin{array}{l}0.286 \\
(0.159)^{*}\end{array}$} & $\begin{array}{l}0.309 \\
(0.162)^{*}\end{array}$ & \multirow[t]{2}{*}{$\begin{array}{l}0.111 \\
(0.19) \\
0.574 \\
(0.339)^{*}\end{array}$} & & \multirow[t]{2}{*}{$\begin{array}{l}0.167 \\
(0.17) \\
0.706 \\
(0.403)^{*}\end{array}$} & \\
\hline & $\begin{array}{l}\text { Debt service to Reserves } \\
\text { Debt service to Reserves*ExF }\end{array}$ & & & & $\begin{array}{l}0.001 \\
0.000 \\
0.001 \\
(0.000)^{* *}\end{array}$ & & $\begin{array}{l}0.001 \\
0.000 \\
0.001 \\
(0.000)^{* *}\end{array}$ \\
\hline \multirow[t]{2}{*}{ Expected return } & $\Delta Y_{-} 1$ & \multirow[t]{2}{*}{$\begin{array}{l}0.002 \\
(0.001)^{*}\end{array}$} & $\begin{array}{l}0.003 \\
(0.001)^{* *}\end{array}$ & $\begin{array}{l}0.002 \\
(0.001)\end{array}$ & $\begin{array}{l}0.002 \\
(0.001)\end{array}$ & \multirow{2}{*}{$\begin{array}{l}0.003 \\
(0.001)^{* *} \\
0.040 \\
(0.013)^{* * *}\end{array}$} & $\begin{array}{l}0.002 \\
(0.001)^{*}\end{array}$ \\
\hline & $\begin{array}{l}\text { Default Dummy } \\
\text { Liquidity Support Dummy }\end{array}$ & & $\begin{array}{l}0.043 \\
(0.013)^{* * *}\end{array}$ & $\begin{array}{l}0.012 \\
(0.018)\end{array}$ & $\begin{array}{l}-0.016 \\
(0.017) \\
\end{array}$ & & $\begin{array}{l}0.035 \\
(0.012)^{* * *}\end{array}$ \\
\hline Observations & & 486 & 482 & 482 & 459 & 482 & 459 \\
\hline Wald & & 25.43 & 30.64 & 28.64 & 26.8 & 31.39 & 29.29 \\
\hline $\log L$ & & -99.54 & -98 & -97.84 & -94.48 & -96.37 & -94.43 \\
\hline Pseudo R2 & & 0.14 & 0.15 & 0.15 & 0.15 & 0.16 & 0.15 \\
\hline
\end{tabular}

Robust standard errors in parentheses

$*$ significant at $10 \% ; * *$ significant at $5 \% ; * * *$ significant at $1 \%$

1/ Variable definitions: i w: world interest rates (U.S. rates); $\Delta$ Y :GDP growth rates; BB: budget balances; Debt: total debt to GDP; CA: current account balances; Reserves to imp: reserves in months of imports; Debt service to reserves: ratio of total debt service to reserves; Reserve to s.t. debt: ratio of reserves in U.S. dollars to total short term debt; $\mathrm{D} / \mathrm{R}$ : dummy identifying countries that underwent a default or a restructuring; ExF: Dummy identifying countries that were granted exceptional financing facilities. 
Table 5. Estimation Methodology: Probit with Instrumental Variables

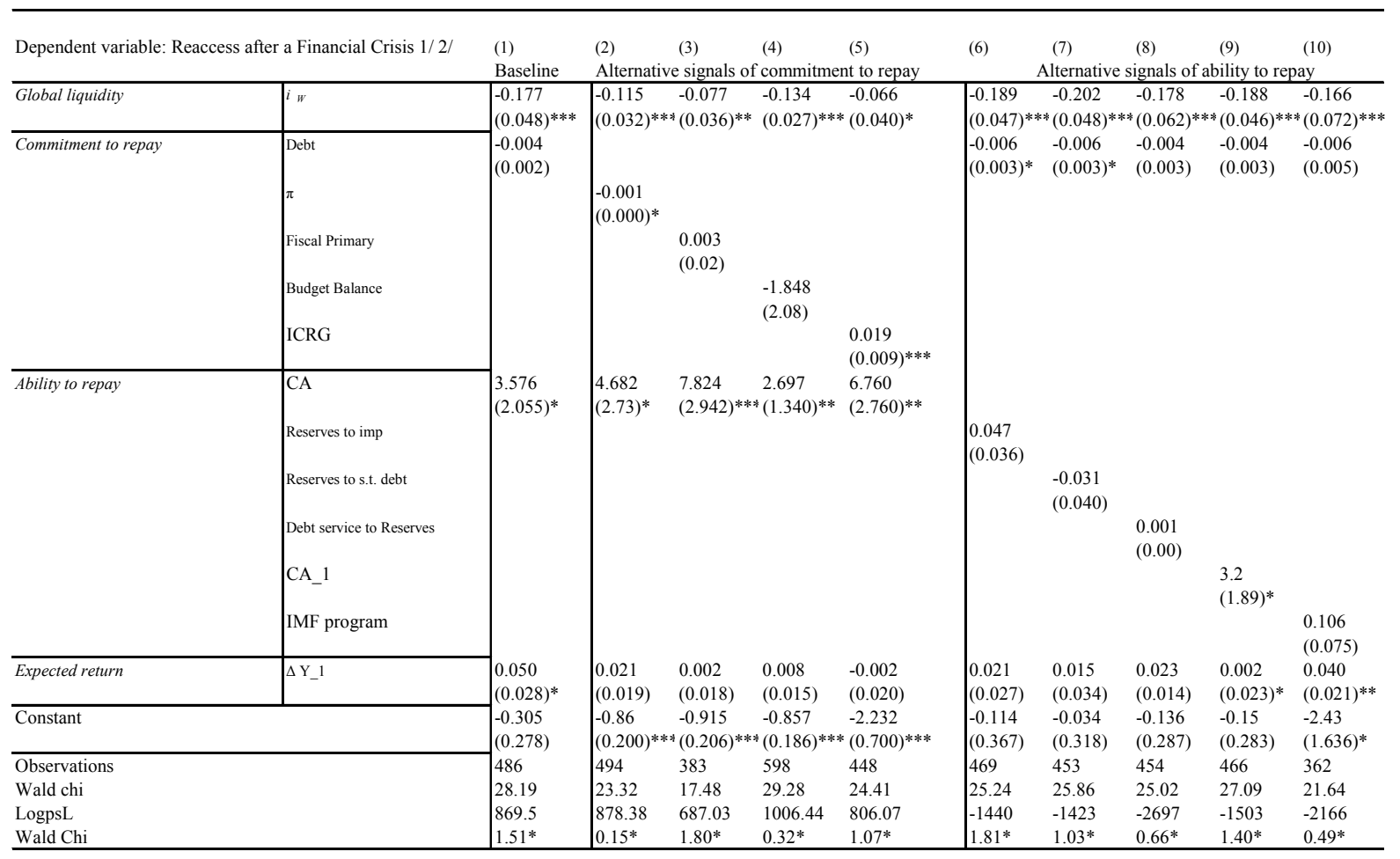

Robust standard errors in parentheses

* significant at $10 \% ;{ }^{* *}$ significant at $5 \% ; * * *$ significant at $1 \%$

1/ Variable definitions: i w: world interest rates (U.S. rates); $\Delta \mathrm{Y}$ :GDP growth rates; Debt: total debt to GDP; CA: current account balances; Reserves to imp: reserves in months of imports; Debt service to reserves: ratio of total debt service to reserves; Reserves to s.t. debt: ratio reserves in U.S. dollars to short term debt; icrg:country risk indicator; IMF program: log size approved IMF program. 


\section{REFERENCES}

Anderson, T. W. and Cheng Hsiao, (1993) The Econometrics of Panel Data. Vol. 1. Elgar Reference Collection series. International Library of Critical Writings in Econometrics; Aldershot, U.K.: Elgar; distributed in the U.S. by Ashgate, Brookfield, Vt.

Atkenson, Andrew, (1991) "International Lending with Moral Hazard and Risk of Repudiation" Econometrical Vol. 59 n.4 (July) pp: 1069-89.

Bulow, Jeremy, and Kenneth Rogoff, (1989a) "A Constant Reconstructing Model of Sovereign Debt” Journal of Political Economy Vol. 97, n.1 (February) pp: 155-78.

Bulow, Jeremy, and Kenneth Rogoff, (1989b) "Sovereign Debt is to Forgive or to Forget?" American Economic Review Vol. 79, n.1 (March) pp: 43-50.

Chambers, John, and Dora Alekseeva, (2002) "Rating Performance 2002, Default, Transition, Recovery, and Spreads," Standard and Poor's.

Cole, Harold L., James Dow, and William B. English, (1995) "Default, Settlement, and Signalling: Lending Resumption in a Reputational Model of Sovereign Debt", International Economic Review, Vol. 36, n. 2, pp: 365-385.

Diamond, Douglas W., (1989) “ Reputation Acquisition in Debt Markets” Journal of Political Economy, Vol. 97, n.4 (November) pp: 828-862.

Eaton, Jonathan, and Mark Gersovitz, (1981) "Debt with Potential Repudiation: Theoretical and Empirical Analysis” Review of Economic Studies Vol. 48, n.2 (April) pp: 289-309.

Eaton, Jonathan, and Raquel Fernandez, (1995) "Sovereign Debt" in Handbook of International Economics. Vol. 3 pp: 2031-77; Handbooks in Economics, Vol. 3. Amsterdam; New York and Oxford: Elsevier, North-Holland, 1995.

Eichengreen, Barry, and Richard Portes, (1986) "Debt and Default in the 1930s: Causes and Consequences”, NBER Working Paper 1772.

Gelos, Gaston R., Ratna Sahay and Guido Sandleris, (2004) "Sovereign Borrowing by Developing Countries: What Determines Market Access?” IMF Working Paper No. 04/221, (Washington: International Monetary Fund).

Green, William, (1997) Econometric Analysis. Prentice-Hall International Limited, London.

Green, William, (2004) "Convenient Estimators for the Panel Probit Model: Further Results" Empirical Economics, Vol. 29 pp: 21-47.

Grigorian, David, (2003) “On The Determinants of First-Time Sovereign Bond Issues" IMF Working Paper No. 03/184, (Washington: International Monetary Fund). 
Grossman, Herschel, I. and John B. Van Huyck, (1988) "Sovereign Debt as a Contingent Claim: Excusable Default, Repudiation and Reputation," American Economic Review, Vol. 78, n.5 pp: 1088-1097.

Hall, Robert E., and Charles I. Jones, (1999) "Why Do Some Countries Produce So Much More Output Per Worker Than Others?” Quarterly Journal of Economics Vol. 114, n.1 pp: 83116.

Hsiao, Cheng, (1996) The Econometrics of Panel Data: A Handbook of the Theory with Applications, second edition. Advanced Studies in Theoretical and Applied Econometrics, Vol. 33. Dordrecht; Boston and London: Kluwer Academic.

International Country Risk Guide (2006) http://www.icrg.org

International Monetary Fund, (2006) World Economic Outlook, Washington, DC.

International Monetary Fund, 2005, "Assessing the Determinants and Prospects for the Pace of Market Access by Countries Emerging from Crises_-Further Considerations," SM/05/76, $(5 / 16 / 05)$.

International Monetary Fund, 2003a, “Access to International Capital Markets for FirstTime Sovereign Issuers,” SM/03/218, (6/24/03).

International Monetary Fund, 2003b, “Access to International Capital Markets for FirstTime Sovereign Issuers - Country Cases,” SM/03/218, (6/24/03).

International Monetary Fund, 2003c, "The Balance Sheet Approach and its Application at the Fund," http://www.imf.org/external/np/pdr/bal/2003/eng/063003.htm, June.

International Monetary Fund, 2003d, Global Financial Stability Report, March.

International Monetary Fund, 2001a, "Assessing the Determinants and Prospects for the Pace of Market Access by Countries Emerging from Crises," EBS/01/157, (9/6/01).

International Monetary Fund, 2001b, "Assessing the Determinants and Prospects for the Pace of Market Access by Countries Emerging from Crises_Country Cases," EBS/01/157, $(9 / 6 / 01)$.

Klingen, Christoph, Beatrice Weder, and Jeromin Zettelmeyer (2004) "How Private Investors Fared in Emerging Debt Markets, 1970-2000”. IMF Working Paper No. 04/13, (Washington: International Monetary Fund).

Knack, Stephen, and Philip Keefer, (1995) "Institutions and Economic Performance: Cross Country Tests Using Alternative Institutional Measures". Economics and Politics Vol. 7, n.3 pp: 207 27. 
Lindert, Peter H. and Peter J. Morton, (1990) "How Sovereign Debt Has Worked", in Developing Country Debt and Economic Performance, Vol. 1, edited by Jeffery Sachs, 39-105. Chicago: University of Chicago Press.

Manasse, Paolo, Nouriel Roubini, and Axel Schimmelpfennig, (2003) "Predicting Sovereign Debt Crises,” IMF Working Paper No. 03/221, (Washington: International Monetary Fund).

Sole Juan, (2004) "Lending Resumption After Default: Lessons from the Capital Markets During the 19th Century” IMF Working Paper No. 06/176, (Washington: International Monetary Fund).

Standard \& Poor, (1997) "Behind the Ratings. Sovereign Credit Ratings: A Primer," Standard \& Poor's CreditWeek, (April 16), pp. 21-28.

Standard and Poor, (2005) "Sovereign Defaults: Heading Lower Into 2006”, September $18^{\text {th }} 2005$.

World Bank (2006) World Development Indicators, CD ROM, Washington, DC. 


\section{List of Countries in Dataset}

\begin{tabular}{ll}
\hline & \multicolumn{1}{c}{ List of Countries } \\
\hline 1 Argentina & 26 Mauritius \\
2 Brazil & 27 Mexico \\
3 Bulgaria & 28 Moldova \\
4 Chile & 29 Morocco \\
5 Colombia & 30 Oman \\
6 Costa Rica & 31 Pakistan \\
7 Croatia & 32 Panama \\
8 Cyprus & 33 Papua New Guinea \\
9 Dominican Republic & 34 Peru \\
10 Ecuador & 35 Philippines \\
11 Egypt & 36 Poland \\
12 El Salvador & 37 Qatar \\
13 Estonia & 38 Romania \\
14 Grenada & 39 Russia \\
15 Guatemala & 40 Saudi Arabia \\
16 Hungary & 41 Slovak Republic \\
17 Indonesia & 42 Slovenia \\
18 Israel & 43 South Africa \\
19 Jamaica & 44 Sri Lanka \\
20 Kazakhstan & 45 Thailand \\
21 Korea & 46 Turkey \\
22 Latvia & 47 Ukraine \\
23 Lebanon & 48 Uruguay \\
24 Lithuania & 49 Venezuela, Rep. Bol. \\
25 Malaysia & \\
\hline
\end{tabular}

